\title{
Relationship between physical activity levels and physical fitness of young (15-17 ages)
}

\author{
Nesrin SAYIN ${ }^{1}$, Adem CIVAN ${ }^{2}$ \\ ${ }^{1}$ Meram Zeki Özdemir High School, Konya, Turkey \\ ${ }^{2}$ Faculty of Sport Sciences, Selcuk University, Konya, Turkey \\ Address correspondence to A. Civan, e-mail: acivan@selccuk.edu.tr
}

\begin{abstract}
The aim of this study was to investigate the relation between physical activity levels and physical fitness of young people (aged 15-17). In total, 200 students participated in this study voluntarily. Physical activity levels were determined by the application of International Physical Activity Questionnaire to the participants. Body composition was also determined by the Body Mass Index calculation. V sit - reach test, 30 seconds sit-up test, 20 meters sprint, 1 mile run and walk test, standing long jump and medicine ball throw tests. The MET scores were calculated for the determination of physical activity levels. The relation with physical fitness was determined by the Pearson correlation test $(p<0.05)$. It was found that the male were physically more active than the female, and the physical activity levels decreased as the age of the participants grow. In conclusion, it can be said that the physical activity level and physical fitness are correlated.
\end{abstract}

Keywords: Physical activity level, physical fitness, youth.

\section{INTRODUCTION}

Human beings always need moving, the place and importance of physical activity are great in human nature. Any movement is regarded as the most fundamental need for human beings, that is, physical activity is necessary to live (22). However, technological developments direct people to physical inactivity dating from childhood and this situation leads to a lifestyle non-appropriate for a human structure (36). The World Health Organization 2002 report explains that a sedentary lifestyle causes 1.9 million people's deaths around the world each year (1).

Physical activity is of physical movements with energy consumption using muscles and joints in a daily life and tiredness at different levels increasing heart and breath rate. In addition to sport activities, exercise, game and various daily activities are also regarded as physical activities. In a daily life four basic fields to be physically active: workplace, transportation, housework's and leisure time activities $(13,36,39)$.
Physical activities have a lot of positive effects on improving body composition, protecting general health, increasing muscle power and balance, preventing and delaying chronic diseases, protecting from musculoskeletal system diseases and treating these diseases, extending life time and improving psychological situations, bringing up children and young people in a healthy way, breaking bad habits, having an active old-age period, shortly, increasing life quality during all life $(5,18,20,28)$.

Physical fitness is an individual's working capacity. This capacity completely depends on an individual's strength, endurance, coordination and quickness. In short, physical fitness is to perform physical activities successfully $(30,35)$. The purpose of physical fitness is to minimize health problem risks at different levels and to reach a high fitness level. The high fitness level and regular exercises are pretty important protecting from heart diseases and other important diseases. Physical fitness involves heart breath endurance, muscle endurance, muscle power, velocity, flexibility, agility, balance, reaction time and body composition parameters $(6,10,19,21)$. The aim of the study was to show relation between physical 
activity levels and physical feasibilities of young people aged 15-17.

\section{MATERIALS \& METHODS}

In this research 100 female and 100 male students aged 15, 16 and 17 participated voluntarily. Firstly, the short form of International Physical Activity Questionnaire was applied to determine the participants' physical activity levels. As the international validity and reliability of the questionnaire were performed by Craig et al., these items were studied on the university students in Turkey by Öztürk. The questionnaire gave information about time for sitting, walking, organizing mild activities and severe activities. In evaluation of all activities, performing any activity at least for 10 minutes was regarded as criteria. By multiplying minutes, days and MET values (time of rest-oxygen consumption), a score was obtained as "MET-minute/week". Physical activity levels were classified as physically non-active ones (<600 MET$\mathrm{min} /$ week), ones with physically low activity level (600 - 3000 MET-min/week) and ones with enough physical activity level (>3000 MET- min/week). In calculation of energy consumption regarding physical activities, the weekly period of any activity (minute) was multiplied with the fixed MET energy values regarding the walk based (3.3 MET), mild (4 MET) and severe (8 MET) physical activity prepared for the International Physical Activity Questionnaire. So the energy consumptions regarding severe, mild, walk based and total physical activities for each individual were taken as MET min/week $(32,39)$.

By estimating physical activity levels, the results were classified as physically non-active, minimal active and maximal active ones. To measure the participants' physical fitness, physical fitness tests were performed. The body composition with the BMI calculation, the flexibility with the $\mathrm{V}$ sit-reach test, the muscle strength and endurance with the 30 sec. sit-up test, the speed with the $20 \mathrm{~m}$ sprint run test, the cardiovascular endurance with the 1 mile run-walk test, quick strength with the long jump by standing and the medicine ball throw tests were given as well. As a result of the questionnaire application, the relation between the physical activity levels and the physical fitness test results was separately evaluated because of the female and male participants' physical fitness differences.

To determine the relation between the physical activity levels and the physical fitness of the young people aged 15-17, the data and the statistical evaluations were given in tables within this study.

\section{RESULTS}

Table 1. Means of age, height, body weight, and body mass index concerning the female and male participants involved in the research.

\begin{tabular}{llcc}
\hline Gender & Variables & Mean & SD \\
\hline Female $(\mathrm{n}=100)$ & Age (years) & 15.92 & 0.84 \\
& Height $(\mathrm{m})$ & 1.62 & 5.24 \\
& Body Weight $(\mathrm{kg})$ & 55.26 & 8.15 \\
& BMI $\left(\mathrm{kg} / \mathrm{m}^{2}\right)$ & 21.20 & 3.21 \\
Male $(\mathrm{n}=100)$ & Age $($ years $)$ & 15.99 & 0.81 \\
& Height $(\mathrm{m})$ & 1.72 & 6.95 \\
& Body Weight $(\mathrm{kg})$ & 63.88 & 12.26 \\
& BMI $\left(\mathrm{kg} / \mathrm{m}^{2}\right)$ & 21.48 & 3.62 \\
\hline
\end{tabular}

Table 2. Means of physical fitness tests concerning the female and male participants involved in the research.

\begin{tabular}{|c|c|c|c|}
\hline Gender & Variables & Mean & SD \\
\hline \multirow{6}{*}{$\begin{array}{l}\text { Female } \\
(\mathrm{n}=100)\end{array}$} & V sit-reach Flexibility $(\mathrm{cm})$ & 10.48 & 5.82 \\
\hline & 30 sec sit-up(numbers) & 16.56 & 5.69 \\
\hline & Long jump by standing $(\mathrm{m})$ & 1.35 & 22.09 \\
\hline & $2 \mathrm{~kg}$ medicine ball throw $(\mathrm{m})$ & 5.37 & 100.48 \\
\hline & $20 \mathrm{~m}$ sprint (sec) & 4.29 & 0.37 \\
\hline & 1 mile run-walk (min/sec) & $8: 97$ & 1.16 \\
\hline \multirow{6}{*}{$\begin{array}{l}\text { Male } \\
(\mathrm{n}=100)\end{array}$} & V sit-reach Flexibility $(\mathrm{cm})$ & 9.02 & 6.06 \\
\hline & 30 sec sit-up ( numbers ) & 23.11 & 4.10 \\
\hline & Long jump by standing $(\mathrm{m})$ & 1.75 & 25.17 \\
\hline & $2 \mathrm{~kg}$ medicine ball throw $(\mathrm{m})$ & 7.89 & 184.85 \\
\hline & 20 m sprint ( $\mathrm{sec}$ ) & 3.59 & 0.25 \\
\hline & 1 mile run-walk $(\mathrm{min} / \mathrm{sec})$ & 6.54 & 1.04 \\
\hline
\end{tabular}


Table 3. Means of physical activity levels concerning the female and male participants involved in the research.

\begin{tabular}{llcc}
\hline Gender & Variables & Mean & SD \\
\hline Female $(\mathrm{n}=100)$ & Total MET ( MET-min/week) & 1926.60 & 1220.34 \\
& Severe FA( MET- min/week ) & 610.48 & 738.96 \\
& Mild FA(MET- min/week ) & 607.71 & 514.86 \\
& Walk-Based FA( MET- min/week ) & 671.76 & 588.58 \\
Male $(\mathrm{n}=100)$ & Total MET( MET- min/week ) & 3856.94 & 1894.78 \\
& Severe FA ( MET- min/week ) & 2292.47 & 1621.67 \\
& Mild FA(MET- min/week ) & 739.71 & 587.24 \\
& Walk-Based FA(MET- min/week ) & 755.98 & 486.90 \\
\hline
\end{tabular}

Table 4. Percentages of the physical activity levels of the female and male participants.

\begin{tabular}{lcccccc}
\hline \multirow{2}{*}{ Physical Activity Level } & \multicolumn{2}{c}{ Female } & \multicolumn{2}{c}{ Male } & \multicolumn{2}{c}{ Total } \\
\cline { 2 - 7 } & $\mathrm{n}$ & $\%$ & $\mathrm{n}$ & $\%$ & $\mathrm{n}$ & $\%$ \\
\hline Non-Active & 10 & 10 & 1 & 1 & 11 & 5.5 \\
Very Active & 17 & 17 & 61 & 61 & 78 & 39 \\
Minimal Active & 73 & 73 & 38 & 38 & 111 & 55.5 \\
\hline
\end{tabular}

Table 5. Relationship between the physical activity levels and physical fitness of the female participants in the study.

\begin{tabular}{lcccccccc}
\hline Female & & $\begin{array}{c}\text { V sit-reach } \\
\text { flexibility }\end{array}$ & $\begin{array}{c}30 \text { sec } \\
\text { sit-up }\end{array}$ & $\begin{array}{c}\text { Long-jump by } \\
\text { Standing }\end{array}$ & $\begin{array}{c}2 \text { kg medicine } \\
\text { ball throw }\end{array}$ & 20 m sprint & $\begin{array}{c}1 \text { mile } \\
\text { run-walk }\end{array}$ & BMI \\
\hline Total MET & $\mathrm{r}$ & 0.135 & 0.098 & 0.100 & $0.318^{*}$ & -0.172 & $-0.209^{*}$ & $0.265^{*}$ \\
& $\mathrm{p}$ & 0.181 & 0.334 & 0.323 & 0.001 & 0.087 & 0.037 & 0.008 \\
Severe FA MET & $\mathrm{r}$ & 0.087 & 0.172 & 0.174 & $0.334^{*}$ & $-0.262^{*}$ & -0.184 & $0.235^{*}$ \\
& $\mathrm{p}$ & 0.388 & 0.088 & 0.084 & 0.001 & 0.008 & 0.067 & 0.018 \\
Mild FA MET & $\mathrm{r}$ & 0.179 & 0.105 & 0.012 & $0.237^{*}$ & -0.018 & -0.032 & $0.244^{*}$ \\
& $\mathrm{p}$ & 0.074 & 0.297 & 0.905 & 0.018 & 0.859 & 0.755 & 0.014 \\
Walk-Based FA MET & $\mathrm{r}$ & 0.027 & 0.053 & -0.047 & -0.003 & 0.040 & $-0.202^{*}$ & 0.041 \\
& $\mathrm{p}$ & 0.787 & 0.603 & 0.643 & 0.978 & 0.693 & 0.044 & 0.686 \\
\hline
\end{tabular}

${ }^{*} \mathrm{p}<0.05$

Table 6. Relationship between the physical activity levels and physical fitness of the male participants in the study.

\begin{tabular}{lcccccccc}
\hline \multirow{2}{*}{ Male } & & $\begin{array}{c}\text { V sit-reach } \\
\text { flexibility }\end{array}$ & $\begin{array}{c}30 \text { sec sit- } \\
\text { up }\end{array}$ & $\begin{array}{c}\text { Long-jump } \\
\text { by Standing }\end{array}$ & $\begin{array}{c}2 \text { kg medicine } \\
\text { ball throw }\end{array}$ & $\begin{array}{c}20 \mathrm{~m} \\
\text { sprint }\end{array}$ & $\begin{array}{c}1 \text { mile } \\
\text { run-walk }\end{array}$ & BMI \\
\hline Total MET & $\mathrm{r}$ & 0.194 & 0.101 & 0.002 & $0.314^{*}$ & -0.037 & $-0.214^{*}$ & $0.258^{*}$ \\
& $\mathrm{p}$ & 0.053 & 0.320 & 0.984 & 0.001 & 0.717 & 0.033 & 0.010 \\
Severe FA MET & $\mathrm{r}$ & 0.154 & 0.176 & 0.050 & $0.265^{*}$ & -0.086 & $-0.225^{*}$ & 0.176 \\
& $\mathrm{p}$ & 0.125 & 0.080 & 0.621 & 0.008 & 0.396 & 0.024 & 0.080 \\
Mild FA MET & $\mathrm{r}$ & 0.041 & 0.104 & -0.094 & 0.053 & 0.093 & -0.115 & $0.223^{*}$ \\
& $\mathrm{p}$ & 0.683 & 0.303 & 0.354 & 0.602 & 0.359 & 0.254 & 0.026 \\
Walk-Based FA MET & $\mathrm{r}$ & $0.232^{*}$ & 0.077 & -0.070 & $0.213^{*}$ & 0.067 & 0.170 & $0.197^{*}$ \\
& $\mathrm{p}$ & 0.020 & 0.445 & 0.490 & 0.033 & 0.505 & 0.092 & 0.050 \\
\hline
\end{tabular}




\section{DISCUSSION}

When generally looked at the results of physical fitness tests, as expected but for the flexibility test, the male participants' all test results were higher than the female participants' test results. In a similar study on the female and male adolescents, while considering the results of physical fitness tests but for the flexibility test, all test results were higher in the male participants $(14,26)$.

In the female participants' parameters of flexibility, sprint, quick strength and endurance some decreases occurred when the age became high. In the male participants' parameters of quick strength and sprint, some positive increases were observed when the age became high, in their flexibility parameters decreases occurred. Savucu et al.'s (33) measured the small, star and young sportmen's physical fitness parameters in their studies, here, the strength, the sprint, the endurance and the anaerobic power increased when the age became high, the flexibility was higher in the sportmen of the star category than the young sportmen. A different study showed that the motor performances of the females in small-aged groups were better than the older ones (38).

When the participants' physical activity levels and physical activity MET points were studied, the male participants had higher total MET, mild physical activity MET and walk-based MET points than the female participants especially in terms of severe physical activity MET points. Mostly, similar results were obtained in many researches applying the International Physical Activity Questionnaire and dealing with various age groups. In these studies the physical activity MET values concerning the male ones were higher than the female ones $(8,15,17,29,32,40)$. As a final part of the study, the males were considered to be physically more energetic than the females. Some studies indicated that the females had more reasons than the males not to participate in the physical activity among the physically non-active high school students $(3,23)$.

According to the female participants' age groups, considering the MET points of the physical activity level, there were decreases in the other MET values except for the MET value of the mild physical activity when the age increased, on the other hand, according to the male participants' age groups, looking at the MET points of the physical activity level, there were decreases in the total and severe physical MET values when the age increased. In the MET values regarding walk there were increases when the age increased. Similar results were found in three different researches on European adolescents. When the group aged between 12,5 and 14,9 and the group aged between 15 and 17,5 were compared in the daily mild and severe physical activity points, the points of the group with an older age were lower the points of the group with a smaller age (27). Also, when compared in the daily total, severe, mild and walk-based physical activity points of the group with 12-14 ages and 15-17 ages, the points of the group with a smaller age were higher than the group with an older age in each field (16). Another research showed that the daily severe, mild and walk-based weekly MET values of the three different groups aged between 14,0-14,9, 15,0-15,9 and 16,0-17,4 reduced when the ages became high (8). Ulusoy (2013) suggested that both the female and male students were more active in the smaller ages in his study about the determination of physical fitness and daily activity levels of young people aged 14-17. Allison et al. (3) described the reasons of less participation in physical activities as extra homeworks, part-time works, economic reasons, environmental factors and home responsibilities among the young people aged $15-16$.

Looking at the the relation between the physical activity levels and the physical fitness test results of the female participants involved in the research, it was seen that the mild and severe physical activity MET points, the total MET points, BMI and medicine ball throw averages were positively related with each other. And it was considered that there was a negative relation between the walk-based MET points, the total MET points and 1 mile run averages, the severe physical activity MET points and the 20 metre sprint run averages. When considered the male participants' physical fitness test results and physical activity levels, there was a positive relation between the mild physical activity, walk-based, total MET points and the BMI, a positive relation between the severe physical activity, walk based, total MET points and the medicine ball throw, a negative relation between the severe physical activity, total MET points and the 1 mile run, a positive relation between the walk-based MET points and the $\mathrm{V}$ sit-reach averages. Contrary to the expected one, the relation between the different activity levels and the BMI was positively linked with each other. The reason for that can be considered as the reasons arising from the growth in different age groups. A significant negative relation was found between the BMI, the physical fitness and endurance tests in a few studies $(12,17)$. 
Although a significant positive relation was found between the physical activity levels and some physical fitness tests in the females and males aged 15 and 16, no statistically significant relation was observed between the physical activity levels and the physical fitness tests of the female and male participants aged 17 when analysing whether there was a relation between the physical activity levels and the physical fitness tests of the female and male participants in accordance with the age groups. The reason of that can be considered as differences in growth and development during the adolescent period.

It was seen that the BMI and the medicine health throw were positively linked with the physical activity levels at different severities, and the 1 mile run averages were negatively linked with them in both the female and male participants. Furthermore, the sprint parameter was also negatively correlated with the 1 mile run and the $20 \mathrm{~m}$ run. In this situation, the run time decreased when the physical activity level increased.

Ottevere et al. (27) identified a positive relation at a medium level between the International Physical Activity Questionnaire (IPAQ) from the methods aimed at determining the physical activity level and the average values of $20 \mathrm{~m}$ sit-up aimed at determining endurance with the accelerometer results in their study about the adolescents aged 12,517. A different study focused on the relation between the physical activity levels and the physical fitness features of the participants aged 10 on average and showed that there was a negative relation between the mild activities and the body fat percentage, and a positive relation between these activities and 20 metre sit-up (34). In another study the physical activity level was evaluated in the university students with the physical activity questionnaire and the cardiorespiratory feasibility measurement, the $\mathrm{VO}_{2}$ max values increased when the participants' activity level increased $(7,9)$. Guvenç et al. (15) suggested in their study about the children aged 8-10 that there was a positive relation between the continuous and frequently recurrent physical activity and the aerobic endurance but a negative relation between this activity and the obesity in both genders. A different study on the young people studying in the secondary school proved that a high level of severe exercise annihilated the harmful effect which the unsedentary time caused on the cardiorespiratory feasibility (24). Denton et al. (11) stated that the cardiorespiratory feasibility was related with the severe and intensive physical activities in the male participants and the mild and severe physical activities in the female participants among the children aged 10-14. A study on the children aged 7-11 found a significant negative relation between the 1 mile run averages and the BMI to determine the maximum oxygen capacity (12). Another study on the children aged 7-10 showed a significant negative relation between the physical fitness, the BMI and the waist circumference measurements in both females and males (17). Tucker et al. (37) revealed about the students studying in the 6-8th class that the BMI, the aerobic capacity, the muscle power and endurance and the flexibility performances were better in the ones who spent their time sedentarily, inertly for 2 hours or less in a day.

Armstrong (4) observed a strong relation between the maximum oxygen uptake capacity and the measurable physical activity values in his study about the children aged 6-8 but a weak relation in the questionnaires dealing with the activity. As a result of this, the questionnaires can be said to be less successful than the other methods in evaluating the physical activity. Morrow et al. (25)'s research on the young people (2013) concluded that the possibility not to have aerobic capacity, BMI, muscle feasibility and healthy physical fitness levels regarding the combination of these three items in the adolescents who could not satisfy the national aerobic and muscle strengthening physical basics was high. Even though a significant relation was found in the low fat level and the severe physical activity in another study, any significant relation could not be observed in the mild and total physical activity levels (31).

In the study, it was concluded that most of the male participants were very active as most of the female participants were active at a minimum level, and as a result of this, the males were physically more active than the females when looking at Table 4 which classified the participants as very active, minimal active and non-active ones.

When their physical activity levels were examined in accordance with their ages, except for the female participants' mild physical activity MET values, their walk-based, severe and total MET values decreased when their ages became high. In the male participants when the ages became high, there were decreases in the severe physical activity and total MET points but increases in the walk-based MET values. When generally studied, there were decreases in the physical activity levels when the ages were high in the female and male participants. 
Looking at the results of the physical fitness tests, as expected from the physical differences, the male participants had a better performance than the female participants. Furthermore, the female participants had decreases in the parameters of flexibility, sprint, quick strength and endurance when the age increased. In the male participants there were increases in the parameters of quick strength and sprint but decreases in the flexibility parameter when the age increased. With the increasing age, the reasons of the low physical activity levels and the physical fitness parameters have been regarded as socio-economic reasons, cultural factors, lack of family support and education system.

When the relation between the physical activity levels and the physical fitness parameters was analyzed, a significant relation was found in the physical activity levels, the endurance, sprint, quick strength parameters at different levels and the BMI among the female and male participants. These results showed us that there was a relation between the physical activity level and the physical fitness. While there was a significant relation between the physical activity levels and the some physical fitness parameters of the female and male participants aged 15 and 16, there was no significant relation between the physical activity levels and physical fitness parameters of the female and male participants aged 17. So the female and male participants aged 15 and 16 were mostly determinants of the research.

In conclusion, it can be said that the physical activity level was linked with the physical fitness, the males aged 15-17 were more physically active than the females, and the physical activity level decreased when generally increasing the age.

\section{REFERENCES}

1. Akyol A, Bilgiç P, Ersoy G. Fiziksel Aktivite, Beslenme ve Sağlikli Yaşam. 1. Baskı. Ankara: Klasmat Matbaacılık, 2008.

2. Allison KR, Dwyer JJ, Goldenberg E, Fein A, Yoshida KK, Boutiller M. Male adolescents' reasons for participating in physical activity. Barriers to participation and suggestions for increasing participation. Spring, 2005; 40(157): 70-155.

3. Allison KR, Dwyer JJ, Makin S. Perceived barriers to physical activity among high school students. Preventive Medicine, 1999; 28(6): 608-615.

4. Armstrong N. Aerobic fitness and physical activity in children. Pediatric Exercise Science, 2013; 25(4): 548-560.

5. Baltaci G. Çocuk ve Spor 1. Baski. Ankara: Klasmat Matbaacilik, 2008.

6. Baltaci G. Fiziksel Aktivite Bilgi Serisi 1. Baskı: Ankara, Klasmat Matbaacilik, 2008.
7. Baş Aslan U, Livanelioğlu A, Aslan Ş. Fiziksel aktivite düzeyinin üniversite öğrencilerinde iki farkli yöntemle değerlendirilmesi. Fizyoterapi Rehabilitasyon, 2007; 18(1): 1119.

8. Cocker KD, Ottevaere C, Sjöström M, Moreno LA, Warnberg J, Valtuena J, Manios Y, Dietrich S,Mauro B, Artero EG, Molnar D, Hagströmer M, Ruiz JR, Sarri K, Kafatos A, Gottrand F, Henauw SD, Maes L, Bourdeaudhuij ID 2010. Self Reported Physical Activity in Europen Adolescents. Results from the HELENA (Healty Lifestyle in Europe by Nutrition in Adolescence) Study. Public Health Nutrition, 2010; 1-9.

9. Cohen KE, Morgan PJ, Plotnikoff RC, Barnett LM, Lubans DR. Improvements in fundamental movement skill competency mediate the effect of the SCORES intervention on physical activity and cardiorespiratory fitness in children. Journal of Sports Sciences, 2015; 33(18): 1908-1918.

10. Çelik E. Gençlerde eklem mobilite düzeyinin fiziksel uygunluğa etkisinin incelenmesi. Yüksek Lisans Tezi. Pamukkale Üniversitesi Sağlik Bilimleri Enstitüsü Fizik Tedavi ve Rehabilitasyon Ana Bilim Dali, Denizli, 2006.

11. Denton SJ, Trenell MI, Plötz T, Savory LA, Bailey DP, Kerr CJ. Cardiorespiratory fitness is associated with hard and light intensity physical activity but not time spent sedentary in 1014 year old school children: the happy study. Plos One, 2013; 8(4):610-23.

12. Esmaeilzadeh S, Kalantari H, Nakhostin-Roohi B 2013. Cardiorespiratory fitness, activity level, health-related anthropometric variables, sedentary behaviour and socioeconomic status in a sample of Iranian 7-11 year old boys. Biol Sport, 2013; 30(1): 67-71.

13. Genç M, Eğri M, Kurçer MA, Kaya M, Pehlivan E, Karaoğlu L, Güneş G. Malatya kent merkezindeki banka çalişanlarinda fizik aktivite sikliği. İnönü Üniversitesi Tip Fakültesi Dergisi, 2002; 9(4): 237-240.

14. Gråstén A. Children's expectancy beliefs and subjective task values through two years of school-based program and associated links to physical education enjoyment and physical activity. Journal of Sport and Health Science, 2015.

15. Güvenç A, Aslan A, Açikada C. Objectively measured activity in 8-10 year old Turkish children. Relationship to healthrelated fitness. Pediatr Int, 2013; 55(5): 629-636.

16. Hagströmer M, Bergman P, Bourdeudhuij ID, Ortega FB, Ruiz JR, Manios Y, Rey-Lopez JP, Phillipp K, Berlepsch J, Sjöström M. Concurrent validity of a modified version of the International Physical Activity Questionnaire (IPAQ-A) in European adolescents: The Helena Study. International Journal of Obesity, 2008; 32: 42-48.

17. Hussey J, Bell C, Bennett K, O’Dwyer J, Gormley J. Reationship between the intensity of physical activity, inactivity, cardiorespiratory fitness and body composition in 7-10 year old Dublin children. Br J Sports Medicine, 2007; 41(5): 311-316.

18. Jaakkola T, Yli-Piipari S, Watt A, Liukkonen J. Perceived physical competence towards physical activity, and motivation and enjoyment in physical education as longitudinal predictors of adolescents' self-reported physical activity. Journal of Science and Medicine in Sport, 2015; 26(1): $74-81$

19. Karacan S, Çolakoğlu FF, Erol AE. Obez orta yaş bayanlar ile menapoz dönemindeki bayanlarda aerobik egzersizin bazi 
fiziksel uygunluk değerlerine etkisi. Erciyes Üniversitesi Sağlik Bilimleri Dergisi, 2004; 3(1): 35-42.

20. Kayihan G, Ersöz G. Hipertansiyon ve egzersiz. Spormetre Beden Eğitimi ve Spor Bilimleri Dergisi, 2009; 7(3): 93-101.

21. Kiliç C. İlköğretim birinci kademe öğrencilerinin bazi fiziksel uygunluk seviyelerinin karşilaştirilmasi. Yüksek Lisans Tezi. Gazi Üniversitesi Sağlik Bilimleri Enstitüsü, Beden Eğitimi ve Spor Anabilim Dali, Ankara, 2007.

22. Kuter FÖ, Kuter M. Beden eğitimi ve spor yoluyla değerler eğitimi. Eğitim ve İnsani Bilimler Dergisi, 2012; 3(6): 80.

23. Memiş UA. Çocukluk ve ergenlikteki fiziksel aktivite deneyimleri ile yetişkinlikteki fiziksel aktivite düzeyi arasindaki ilişki. Doktora Tezi. Gazi Üniversitesi Eğitim Bilimleri Enstitüsü, Beden Eğitimi ve Spor Öğretmenliği Anabilim Dali, Ankara, 2007.

24. Moore JB, Beets MW, Barr-Anderson DJ, Evenson KR Sedentary time and vigorous physica activity are independently associated with cardiorespiratory fitness in middle school youth. J Sports Science, 2013; 31(14): 1520-1525.

25. Morrow JR, Tucker JS, Jackson AW, Martin SB, Greenleaf CA, Petrie TA. Meeting physical activity guidelines and healthrelated fitness in youth. Am J Prev Med, 2013; 44(5): 439-444.

26. Ortega FB, Artero EG, Ruiz JR, Rodriguez GV, Bergman $P$, Hastgrömer M, Ottevaere C, Nagy E, Konsta O, Lopez JPR, Polito A, Dietrich S, Plada M, Beghin L, Manios Y, Sjöström M, Castillo MJ. Reliability of health-related physical fitness tests in European adolescents. The Helena Study. International Journal of Obesity, 2008; 32: 49-57.

27. Ottevaere C, Huybrechts I, Bourdeaudhuij ID, Sjöström M, Ruiz JR, Ortega FB, Hastgrömer M, Widhalm K, Molnar D, Moreno LA, Beghin L, Kafatos A, Polito A,Manios Y, Gomez DM, Henauw SD. Comparison of the IPAQ-A and actigraph in relation to $\mathrm{VO}_{2}$ max among European adolescents: The HELENA Study. Journal of Science and Medicine in Sport, 2011; $14: 317-324$

28. Özkan A, Bozkuş T, Kul M, Türkmen M, Öz Ü, Cengiz C. Halk oyuncularinin fiziksel aktivite düzeyleri ile sağlikli yaşam biçimi davranişlarinin belirlenmesi ve ilișkilendirilmesi. International Journal of Science Culture and Sport, 2013; 1(3): 24-28.

29. Polat B, Göksel HÇ. Determination of Candidate Teachers Social Activity
Preferences by Pair-Wise Comparision Scaling Method. Journal of Measurement and Evaluation in Education and Psychology, $2014 ; 5,1$.

30. Polat $Y$, Çinar V, Şahin M, Yalçin R. Futbolcu Çocuklarin Fiziksel Uygunluk Düzeylerinin İncelenmesi. İstanbul Üniversitesi Spor Bilimleri Dergisi, 2003; 11(3): 196-199.

31. Ruiz JR, Rizzo NS, Hurting-Wennlöf A, Ortega FB, Warnberg J, Sjöström M. Reations of total physical activity and intensity to fitnes and fatnessin children: the Europen Youth Heart Study. Am J Clin Nutrition, 2006; 84(2): 299-303.

32. Savci S, Öztürk M, Arikan H, İnce Dİ, Tokgözoğlu L. Üniversite öğrencilerinin fiziksel aktivite düzeyleri. Türk Kardiyoloji Derneği Dergisi, 2006; 34(3): 166-172.

33. Savucu Y, Polat Y, Ramazanoğlu F, Karahüseyinoğlu MF, Biçer YS. Alt yapıdaki küçük, yıldız ve genç basketbolcuların bazı fiziksel uygunluk parametrelerinin incelenmesi. Firat Üniversitesi Sağlik Bilimleri Dergisi, 2004; 18(4): 205-209.

34. Saygin Ö, Dükanci Y. Kız çocuklarda sağlık ilişkili fiziksel aktivite yoğunluğu ilişkisinin araştırılması. Uluslararasi İnsan Bilimleri Dergisi, 2009; 6(1): 320-329.

35. Saygin Ö, Polat Y, Karacabey K. Çocuklarda hareket eğitiminin fiziksel uygunluk özelliklerine etkisi. Firat Üniversitesi Sağlk Bilimleri Dergisi, 2005; 19(3): 205-212.

36. Şanli E. Öğretmenlerde fiziksel aktivite düzeyi-yaş, cinsiyet ve beden kütle indeksi ilişkisi. Yüksek Lisans Tezi. Gazi Üniversitesi Eğitim Bilimleri Enstitüsü, Beden Eğitimi ve Spor Öğretmenliği Anabilim Dali, Ankara, 2008.

37. Tucker JS, Martin S, Jackson AW, Morrow JR, Greenleaf CA, Petrie TA. Relationship between sedentary behavior and FITNESSGRAM healty fitness zone achievement and physical activity. J Physical Activitiy Health, 2013.

38. Ulusoy C. 14-17 yaş arasindaki gençlerin fiziksel uygunluklarinin ve günlük aktivite düzeylerinin belirlenmesi. Yüksek Lisans Tezi. Yakin Doğu Üniversitesi Sağlik Bilimleri Enstitüsü, Beden Eğitimi ve Spor Programı, Lefkoşa, Republic of North Cyprus Turkish, 2013.

39. Vural Ö, Eler S, Atalay Güzel N. Masa başı çalışanlarda fiziksel aktivite düzeyi ve yaşam kalitesi ilişkisi. Spormetre Beden Eğitimi ve Spor Bilimleri Dergisi, 2010; 8(2): 69-75.

40. Wolin KY, Heil DP, Askew S, Matthews CE, Bennett GG. Validation of the International Physical Activity Questionnaire-Short among blacks. J Phys Act Health, 2008; 5(5): 746-760. 